\title{
Effect of raw and post bio-methanated spent wash bio-compost on the growth, yield quality of seasonal sugarcane chemical properties of sodic soil
}

M.R. CHAUHAN AND A. L. PHARANDE

Received : 03.05.2017; Revised : 01.11.2017; Accepted : 11.11.2017

MEMBERS OF RESEARCH FORUM:

Corresponding author :

M.R. CHAUHAN, Department of soil Science and Agricultural

Chemistry, Mahatma Phule Krishi

Vidyapeeth, Ahmednagar, RAHURI (M.S.) INDIA

Co-authors :

A. L. PHARANDE, Department of soil Science and Agricultural Chemistry, Mahatma Phule Krishi Vidyapeeth, Ahmednagar, RAHURI (M.S.) INDIA

\section{Summary}

A field experiment was conducted at Post Graduate Institute, Mahatma Phule Krishi Vidyapeeth Rahuri, dist- Ahmednagar ( M.S.) with raw and post bio-methanated spent wash for preparation of bio-compost from the different organic sources like press mud cake, baggasse, sugarcane trash, farm waste like pearl millet straw, chickpea straw and wheat cut straw etc. and seasonal sugarcane crop (Saccharum officinarum) variety Co 86032 was planted with sixteen treatments, three replications in sodic soil. Absolute control, farm yard manure and vermicompost treatments were taken for comparison with bio-composts. The growth parameters like height of the plant, girth of the stem, number of tillers etc. as well as yield, quality of sugarcane and soil chemical properties etc. were found significantly higher in the post bio-methanated biocompost treatment as compared to the raw spent wash bio-compost treatment under sodic soil condition.

Key words : Spent wash, Post bio-methanated, Farm yard manure, Pearl millet, Vermicompost

How to cite this article : Chauhan, M.R. and Pharande, A. L. (2017). Effect of raw and post biomethanated spent wash bio-compost on the growth, yield quality of seasonal sugarcane chemical properties of sodic soil. Asian J. Soil Sci., 12 (2) : 233-241 : DOI : 10.15740/HAS/AJSS/12.2/233-241. 